\title{
Glucocorticoid-Induced Leucine Zipper Promotes Neutrophil and T-Cell Polarization with Protective Effects in Acute Kidney Injury
}

\author{
Babak Baban, Cristina Marchetti, Hesam Khodadadi, Aneeq Malik, Golnaz Emami, \\ Ping-Chang Lin, Ali S. Arbab, Carlo Riccardi, and Mahmood S. Mozaffari \\ Department of Oral Biology and Diagnostic Sciences, Dental College of Georgia (B.B., H.K., A.M., G.E., M.S.M.) and Georgia \\ Cancer Center (P.-C.L., A.S.A.), Augusta University, Augusta, Georgia; and Department of Medicine, University of Perugia, \\ Perugia, Italy (C.M., C.R.) \\ Received June 14, 2018; accepted October 1, 2018
}

\section{ABSTRACT}

The glucocorticoid-induced leucine zipper (GILZ) mediates antiinflammatory effects of glucocorticoids. Acute kidney injury (AKI) mobilizes immune/inflammatory mechanisms, causing tissue injury, but the impact of GILZ in AKI is not known. Neutrophils play context-specific proinflammatory [type 1 neutrophil (N1)] and anti-inflammatory [type 2 neutrophil (N2)] functional roles. Also, regulatory $\mathrm{T}$ lymphocytes (Tregs) and regulatory $\mathrm{T}-17$ (Treg17) cells exert counterinflammatory effects, including the suppression of effector T lymphocytes [e.g., T-helper (Th) 17 cells]. Thus, utilizing cell preparations of mice kidneys subjected to AKI or sham operation, we determined the effects of GILZ on T cells and neutrophil subtypes in the context of its renoprotective effect; these studies used the transactivator of transcription (TAT)-GILZ or the TAT peptide. AKI increased N1 and Th-17 cells but reduced N2, Tregs, and Treg17 cells in association with increased interleukin (IL) $-17^{+}$but reduced
IL- $10^{+}$cells accompanied with the disruption of mitochondrial membrane potential $\left(\psi_{\mathrm{m}}\right)$ and increased apoptosis/necrosis compared with sham kidneys. TAT-GILZ, compared with TAT, treatment reduced $\mathrm{N} 1$ and Th-17 cells but increased $\mathrm{N} 2$ and Tregs, without affecting Treg17 cells, in association with a reduction in $\mathrm{IL}-17^{+}$cells but an increase in IL-10 ${ }^{+}$cells; TATGILZ caused less disruption of $\psi_{\mathrm{m}}$ and reduced cell death in AKI. Importantly, TAT-GILZ increased perfusion of the ischemicreperfused kidney but reduced tissue edema compared with TAT. Utilizing splenic T cells and bone marrow-derived neutrophils, we further showed marked reduction in the proliferation of Th cells in response to TAT-GILZ compared with response to TAT. Collectively, the results indicate that GILZ exerts renoprotection accompanied by the upregulation of the regulatory/suppressive arm of immunity in AKI, likely via regulating cross talk between $\mathrm{T}$ cells and neutrophils.

\section{Introduction}

Glucocorticoids have long been known for their remarkable anti-inflammatory effects and used for a variety of conditions associated with dysregulation of immune and inflammatory responses. Nonetheless, their metabolic effects often present limitations and challenges to fully harness their beneficial antiinflammatory effects (Fan and Morand, 2012). Thus, intense research has focused on identifying molecular mechanisms mediating anti-inflammatory effects of glucocorticoids with the ultimate objective of avoiding their adverse metabolic effects. This search has led to the discovery of the glucocorticoid-induced leucine zipper (GILZ) protein, a member of the TSC-22D family with remarkable similarity in amino acid sequence between human and mouse, as a very predictive and responsive target of glucocorticoids and mediator of their anti-inflammatory effects

This study was in part supported by an institutional Extramural Success Award. No potential conflicts of interest relevant to this article are reported. https://doi.org/10.1124/jpet.118.251371.
(D’Adamio et al., 1997; Riccardi et al., 1999; Cannarile et al., 2001; Ayroldi and Riccardi, 2009; Fan and Morand, 2012; Bereshchenko et al., 2014; Ronchetti et al., 2015). Consequently, GILZ is shown to beneficially impact several conditions associated with dysregulation of immune and inflammatory responses including myocardial infarction (Cannarile et al., 2009; Beaulieu et al., 2010; Fan and Morand, 2012; Jones et al., 2015; Baban et al., 2017; Srinivasan and Lahiri, 2017; Yang et al., 2017). However, the impact of GILZ on pathologies involving the kidney remains largely unexplored.

Acute kidney injury (AKI) is a major public health concern, worldwide, and is estimated to affect about 13 million patients each year; its hallmark features include an abrupt decline in kidney function and derangement of its ultrastructure (Fry and Farrington, 2006; Makris and Spanou, 2016; Zuk and Bonventre, 2016). AKI describes a syndrome of disorders composed of three primary etiologies: prerenal, postrenal, and intrinsic. Importantly, intrinsic acute tubular necrosis is most commonly attributable to ischemic injury, contributing to about $50 \%$ of the cases of acute renal failure (Torras et al., 2002; Spurgeon-Pechman et al., 2007;

ABBREVIATIONS: AKI, acute kidney injury; GILZ, glucocorticoid-induced leucine zipper; GST, glutathione S-transferase; IL, interleukin; IRI, ischemia reperfusion injury; LPS, lipopolysaccharide; Ly-6G, lymphocyte antigen 6 complex locus G6D; $\psi_{\mathrm{m}}$, mitochondrial membrane potential; MLR, mixed lymphocytic reaction; MRI, magnetic resonance imaging; N1, type 1 neutrophil; N2, type 2 neutrophil; PBS, phosphate-buffered saline; STAT3, signal transducer and activator of transcription 3; TAT, transactivator of transcription; Teff, effector T lymphocyte; Th, T-helper; TNF- $\alpha$, tumor necrosis factor- $\alpha$; Treg, regulatory T cell; Treg17, regulatory T-17. 
O'Neal et al., 2016). Several clinical conditions are associated with renal ischemia-reperfusion injury (IRI), including renal transplantation, partial nephrectomy, cardiac surgery, shock, and repair of some forms of abdominal aneurysms. Indeed, kidney transplantation-associated IRI contributes to delayed graft function, delayed graft rejection, acute rejection, and chronic allograft nephropathy (Velic et al., 2005; Menke et al., 2014; Schröppel and Legendre, 2014).

Sterile inflammation is a hallmark feature of IRI-induced renal injury. It is characterized by marked induction of chemokines, which provide directional signals for the recruitment of leukocyte subpopulations into the damaged tissue, accompanied by the activation of cells of the innate and adaptive immunity (Ko et al., 2010; Li and Okusa, 2010; Kinsey et al., 2013; Denecke and Tullius, 2014; Inoue and Okusa, 2015; Jang and Rabb, 2015). Although inflammation is critical to healing of the injured tissue, excessive and/or prolonged inflammation can exacerbate tissue injury. The mechanisms contributing to the upregulation of an inflammatory response have been the focus of intense investigation; however, mechanisms that contain and resolve inflammation are increasingly being uncovered. Consequently, it is shown that cells of innate and adaptive immunity can undergo context-specific polarization resulting in functional phenotypes consistent with proinflammatory or anti-inflammatory outcomes (Schröppel and Legendre, 2014; Makris and Spanou, 2016). Neutrophils are recruited into the kidney very early postIRI (Lauriat and Linas, 1998; Bolisetty and Agarwal, 2009). Recent studies (Ma et al., 2016; Baban et al., 2018) indicate the capacity of neutrophils to assume proinflammatory and antiinflammatory functional phenotypes [i.e., type 1 neutrophil (N1) and type 2 neutrophil (N2), respectively], depending on microenvironment cues and via the expression of specific cell markers. Similarly, T cells can undergo polarization to their suppressive/ regulatory phenotypes, regulatory $\mathrm{T}$ cells (Tregs), which curtail effector T lymphocytes (Teffs) (Fan and Morand, 2012; Makris and Spanou, 2016). Interestingly, recent studies (Chaudhry et al., 2009; Kluger et al., 2016) have identified a subset of Tregs, which counteract T-helper (Th) 17 cell-specific responses [i.e., regulatory T-17 (Treg17) cells]. Thus, therapies that promote suppressive/regulatory phenotypes of innate (e.g., neutrophils) and adaptive (i.e., T cells) immunity should be protective in AKI.

In light of emerging reports indicating prominent antiinflammatory properties of GILZ, we tested the hypothesis that exogenous delivery of GILZ should restore the imbalance among neutrophil subtypes and Tregs/Treg17 cells versus Th-17 cells, thereby curtailing the intense inflammatory response of the kidney subjected to IRI, culminating in protective effects. For these studies, we used the cell-permeable transactivator of transcription (TAT)-GILZ fusion protein (Vago et al., 2015). The results indicated a marked impact of GILZ on the upregulation of regulatory/suppressive phenotypes of neutrophils and $\mathrm{T}$ cells in association with renoprotection in AKI. Thus, subsequent in vitro studies used the functional assay mixed lymphocytic reaction to determine whether GILZ affects cross talk between $\mathrm{T}$ cells and neutrophils in relation to $\mathrm{T}$ cell proliferation.

\section{Materials and Methods}

Animals. Male BALB/c mice, 9-11 weeks of age, were obtained from Harlan Laboratories (Frederick, MD). The animals were housed in the laboratory animal facilities of Augusta University with free access to food and water. The use of male mice relates to greater susceptibility of the male sex to AKI (Neugarten et al., 2018), and rodents of similar age are routinely used for the investigation of various pathologies. The use of animals for this study conformed to the guidelines of Institutional Animal Care and Use Committee.

TAT and TAT-GILZ. The TAT peptide and the TAT-GILZ fusion protein were generated as described previously (Vago et al., 2015). Briefly, TAT and TAT-GILZ, which was constructed by inserting GILZ cDNA into the TAT $\mathrm{C}$ vector to produce an in-frame fusion protein, were cloned into the pGEX-4T2 plasmid (GE Healthcare, Chicago, IL). The pGEX-4T2 plasmid is a glutathione $S$-transferase (GST) fusion vector carrying a tac promoter for chemically inducible high-level expression of the protein. GST fusion protein was expressed in lipopolysaccharide (LPS)-lacking bacteria, ClearColi BL21 (Lucigen, Middleton, WI), which was grown at $37^{\circ} \mathrm{C}$ and induced with $1 \mathrm{mM}$ isopropyl $\beta$-D-thiogalactopyranoside for 4 hours (Mamat et al., 2015); all the other materials used in the process were sterile and LPS free. After lysis by sonication, most of the induced protein was found in the soluble fraction, which was then purified with glutathione-Sepharose 4B beads (GE Healthcare) following the manufacturer instructions. Eluted proteins were dialyzed against PBS for 48 hours.

Induction of Renal IRI and Treatment Protocols. After ketamine (120 mg/kg, i.p.)/xylazine (16 mg/kg, i.p.) anesthesia, two flank incisions were made followed by clamping of the left renal pellicle, for 20 minutes, using a nontraumatic vascular clamp. Thereafter, the vascular clamp was removed and the restoration of renal blood flow was confirmed visually prior to the closure of muscle and skin layers using 4-0 silk sutures and autoclips, respectively (Mozaffari et al., 2010; Baban et al., 2012); the right kidney in each animal served as a sham control. The animals were further subdivided to receive intraperitoneal administration of either TAT $(0.1 \mathrm{mg} / \mathrm{kg})$ or TAT-GILZ $(0.2 \mathrm{mg} / \mathrm{kg})$ delivered in $50 \mu \mathrm{l}$ of PBS 10 minutes before removal of the vascular clamp; the dosage regimen is based on 2 -fold larger molecular weight of GST-TAT-GILZ than GST-TAT as well as on studies indicating the resolution of LPS-induced inflammation in response to TAT-GILZ treatment (Vago et al., 2015). Postoperative analgesia was provided with a single injection of buprenorphine ( $1 \mathrm{mg} / \mathrm{kg}$, s.c.). The animals were sacrificed 1 day postinjury, and kidneys were procured for cell preparation and flow cytometry-based assays.

Flow Cytometry. Single-cell suspension was prepared for each mouse kidney and subjected to flow cytometry-based assays (Baban et al., 2009, 2012, 2018) to identify and analyze the numbers of total and subtypes of neutrophils and T cells as follows: neutrophils were initially identified as $\mathrm{Ly}-6 \mathrm{G}^{+} / \mathrm{CD} 11 \mathrm{~b}^{+}$cells and were presented as a percentage of whole kidney cells. Neutrophils were further identified as N1 (proinflammatory neutrophils) and N2 (regulatory neutrophils) using combinations of surface and intracellular markers, including Ly- $6 \mathrm{G}^{+} / \mathrm{CD} 11 \mathrm{~b}^{+}$and tumor necrosis factor- $\alpha(\mathrm{TNF}-\alpha)$ for N1s and Ly- $6 \mathrm{G}^{+} / \mathrm{CD} 11 \mathrm{~b}^{+} / \mathrm{CD} 206^{+}$, and interleukin (IL)-10, for N2s. As for $\mathrm{T}$ cells, they were initially identified as $\mathrm{CD} 45^{+} / \mathrm{CD}^{+} / \mathrm{CD}^{+}$for Teffs followed by further analyses as Th- 17 cells $\left(\mathrm{CD} 45^{+} / \mathrm{CD}^{+} / \mathrm{CD} 4^{+}\right.$ $\left./ \mathrm{IL}-17^{+}\right)$and Tregs $\left(\mathrm{CD} 45^{+} / \mathrm{CD}^{+} / \mathrm{CD}^{+} / \mathrm{FOXP}^{+}\right)$; Tregs were further characterized for the identification of Treg- 17 cells as CD $45^{+} / \mathrm{CD}^{+} /$ $\mathrm{CD}^{+} / \mathrm{FOXP}^{+} / \mathrm{CD} 196^{+} / \mathrm{STAT}^{+}$cells. For these studies, antibodies were procured from BioLegend (San Diego, CA). After incubation, all stained cells were washed and resuspended in $400 \mu \mathrm{l}$ of flow cytometry staining buffer and analyzed using CellQuest software through a fourcolor BD FACSCalibur Flow Cytometer (BD Biosciences, San Jose, CA). As a gating strategy, isotype-matched controls were analyzed in each sample to set the appropriate gates; representative flow cytometry panels/data are reported in each relevant figure. For each marker, samples were analyzed with duplicate measurements. To minimize false-positive events, the number of double-positive events detected with the isotype controls was subtracted from the number of doublepositive cells stained with corresponding antibodies (i.e., not isotype control).

The assessment of $\psi_{\mathrm{m}}$ used the JC-1 assay, whereas apoptotic/ necrotic cell death in whole kidney cell preparations was determined 
using 7-aminoactinomycin D/caspase-3 assay as described previously (Baban et al., 2012, 2018).

The Mixed Lymphocytic Reaction. In light of the marked impact of TAT-GILZ treatment on the polarization of neutrophils and $\mathrm{T}$ cells, we used the mixed lymphocytic reaction (MLR) assay to determine whether GILZ regulates the interaction of neutrophils with $\mathrm{T}$ cells in relation to their proliferation. Accordingly, responder $\mathrm{T}$ lymphocytes from spleens of BALB/c mice were enriched using magnetic activated cell sorting (Miltenyi Biotec, Bergisch Gladbach, Germany), labeled with $5 \mu \mathrm{M}$ carboxyfluorescein succinimidyl ester for 10 minutes at $37^{\circ} \mathrm{C}$, and plated at $1 \times 10^{4}$ cells/well. Neutrophils $\left(\mathrm{LY}-6 \mathrm{G}^{+} / \mathrm{CD} 11 \mathrm{~b}^{+}\right)$were prepared from the bone marrow of $\mathrm{C} 57 \mathrm{BL} / 6$ mice, using magnetic activated cell sorting, and were used as stimulators $\left(1 \times 10^{5}\right.$ cells/well). Combinations of responders (naive $\mathrm{T}$ lymphocytes) and stimulators (neutrophils) were prepared in triplicate wells. Cells were cultured in $200 \mu \mathrm{l} /$ well RPMI 1640 medium supplemented with fetal bovine serum, penicillin, streptomycin, l-glutamine, and 2-methoxyestradiol. Wells were treated based on experimental design, without or with $2.5 \mu \mathrm{g} / \mathrm{ml}$ TAT-GILZ or TAT. After 72 hours of incubation in a humidified incubator, with $5 \% \mathrm{CO}_{2}$ at $37^{\circ} \mathrm{C}$, cells were harvested into flow cytometry tubes. After a PBS wash, samples were incubated at $4^{\circ} \mathrm{C}$ for 20 minutes in the dark with anti-rat CD71-phycoerythrin-conjugated antibody to label activated and dividing T cells. Samples were washed with PBS, and T-cell proliferation was assessed in triplicate by flow cytometry (Baban et al., 2009, 2017).

Renal Magnetic Resonance Imaging. The protocol for unilateral renal IRI and treatment with TAT or TAT-GILZ were similar to that described above except that animals received daily injections of TAT and TAT-GILZ until sacrificed ( $n=3$ per condition). Accordingly, multiple magnetic resonance imaging (MRI) scan protocols were carried out on each animal on day 1 and day 5, after renal IRI and treatment with either TAT or TAT-GILZ at the Core Imaging Facility for Small Animals of Georgia Cancer Center, Augusta University (Hueper et al., 2016). The imaging protocols were executed on a 7-T/20-cm horizontal-bore Bruker Advance MRI Spectrometer (Bruker Biospin, Billerica, MA) equipped with a gradient system (BGA06; Bruker Biospin) of $950 \mathrm{mT} / \mathrm{m}$ in gradient strength. A standard Bruker transmit/receive volume coil of $35 \mathrm{~mm}$ internal diameter was used for imaging. Anesthesia was maintained with $1.5 \%$ isoflurane and a mix of $\mathrm{O}_{2}$ /medical air during MRI, and animals were placed in the prone position with body temperature maintained at $37^{\circ} \mathrm{C}$ using warm air in the animal cradle. The respiratory signal was monitored by a physiologic monitoring system (Model 1025T; Small Animal Instruments, Inc., Stony Brook, NY). Initial imaging using a three-orthogonal plane two-dimensional T1-weighted fast, low-angle shot was acquired in the abdominal area to guide the slice settings of renal MRI on the coronal plane. Renal images were acquired using the following pulse sequences: 1) fast spin-echo sequence was used to acquire multislice multiecho T2-weighted images in coronal orientation to create T2 maps for the assessment of tissue edema and 2) arterial spin-labeling images were acquired using flow-sensitive alternating inversion recovery sequence in coronal orientation to determine renal perfusion. Image analysis, including region-ofinterest selection and further analysis for tissue perfusion and edema, was conducted using ImageJ (NIH, Bethesda, MD) (Schneider et al., 2012). As the index of renal blood flow, tissue perfusion was obtained as intensity per square millimeter, which was used to calculate the ratio of left kidney (i.e., ischemic reperfused) to right kidney (sham control) for each mouse. Edema in renal tissues (i.e., cortical and medullary segments) was also determined using T2 maps and expressed in milliseconds. At the conclusion of these studies, animals were sacrificed and kidney weights were determined for each animal.

Statistics. Analysis of variance was used followed by NewmanKeuls post hoc test to establish significance $(P<0.05)$ among groups; kidney perfusion data (Fig. 6) of TAT-treated and TAT-GILZ-treated animals were analyzed for significance $(P<0.05)$ using the Student $t$ test. Data are reported as the mean \pm S.E.M.

\section{Results}

TAT-GILZ Promotes Neutrophil Polarization in Favor of N2 in AKI. Figure 1 shows representative flow cytometry panels indicating phenotypic (Fig. 1A, dot plots) and functional (Fig. 1B, dot plots) analysis of neutrophils and their subtypes; Fig. 1, C and D shows quantitative data for total renal neutrophils and their subtypes, respectively, whereas the inset of Fig. 1D shows the N1/N2 ratio for experimental groups. Total neutrophils, expressed as a percentage of whole kidney cells, were significantly increased in the ischemic-reperfused kidneys compared with the sham-operated kidneys (Fig. 1C), with dominance of the N1 rather than the N2 subtype (Fig. 1D) for TAT-treated mice. Treatment with TAT-GILZ caused a significant decrease in total kidney neutrophils in ischemicreperfused kidneys, achieving levels similar to sham-operated kidneys (Fig. 1C). Importantly, TAT-GILZ treatment significantly decreased N1 frequency but increased N2 frequency in ischemic-reperfused kidneys compared with their TAT-treated counterparts (Fig 1, C and D). Consequently, renal IRI in TATtreated mice caused a prominent increase in $\mathrm{N} 1 / \mathrm{N} 2$ ratio, an effect markedly and significantly reduced in response to TATGILZ treatment (Fig. 1D, inset). Further assessment indicates that TAT-GILZ treatment preserves N2 functionality, as exemplified by dot plots for IL-10, compared with TAT treatment (Fig. 1B); similarly, TNF- $\alpha$ was used for the assessment of the status of $\mathrm{N} 1 \mathrm{~s}$ (Fig. 1B).

TAT-GILZ Promotes Development of Tregs but Reduces Th-17 Cells in AKI. Figure 2 shows the impact of renal IRI and TAT-GILZ treatment on the polarization of $\mathrm{T}$ cells. Accordingly, preparations of whole kidney cells were initially analyzed to identify Teffs $\left(\mathrm{CD} 45^{+} / \mathrm{CD} 3^{+}\right)$followed by further analysis to show Th- 17 cells $\left(\mathrm{CD} 45^{+} / \mathrm{CD} 3^{+} / \mathrm{IL}-17^{+}\right)$, induced Tregs $\left(\mathrm{CD} 45^{+} / \mathrm{CD}^{+} / \mathrm{FoxP}^{+}\right)$, and Treg17 cells $\left(\mathrm{CD} 45^{+} / \mathrm{CD}^{+}{ }^{+} / \mathrm{FOXP}^{+} / \mathrm{CD} 196^{+} / \mathrm{STAT}^{+}{ }^{+}\right.$) (Fig. 2 , A and B). Total Teffs, expressed as the percentage of total T cells, were similar between the TAT-treated and TAT-GILZ-treated sham kidneys $(91.4 \pm 0.8$ vs. $90.6 \pm 0.5)$ but lower than the TAT-treated ischemic-reperfused kidneys $(96.9 \pm 0.4 ; P<$ $0.05)$. Treatment with TAT-GILZ reduced Teffs in ischemicreperfused kidneys $(93.1 \% \pm 1.1 \%)$. Th-17 cells were significantly higher in TAT-treated IRI kidneys compared with their sham controls; TAT-GILZ treatment of IRI kidneys partially, but significantly, reduced the number of Th-17 cells compared with their TAT-treated counterparts (Fig. 2B). Although Tregs were similar between TAT-treated and TAT-GILZ-treated sham kidneys, IRI caused a significant reduction in Tregs in kidneys of TAT-treated animals compared with their shamoperated kidneys (Fig. 2C). Importantly, TAT-GILZ treatment resulted in a significant increase in Tregs compared with their TAT-treated counterparts, largely restoring their frequency to levels of sham kidneys (Fig. 2C). Similarly, Treg17 cells were reduced in TAT-treated and TAT-GILZ-treated ischemicreperfused kidneys compared with their sham-operated counterparts; treatment with TAT-GILZ did not significantly affect the frequency of Treg 17 cells in ischemic-reperfused kidneys compared with their TAT-treated counterparts (Fig. 2D).

TAT-GILZ Reduces $\mathrm{IL}^{-17^{+}}$but Increases $\mathrm{IL}^{+} \mathbf{1 0}^{+}$Cells in AKI. Figure 3 shows the percentage of IL- $17^{+}$and IL- $10^{+}$ cells in whole kidney cell preparations of experimental groups. Treatment of ischemic-reperfused kidneys with either TAT or TAT-GILZ significantly increased the frequency of IL- $17^{+}$ 

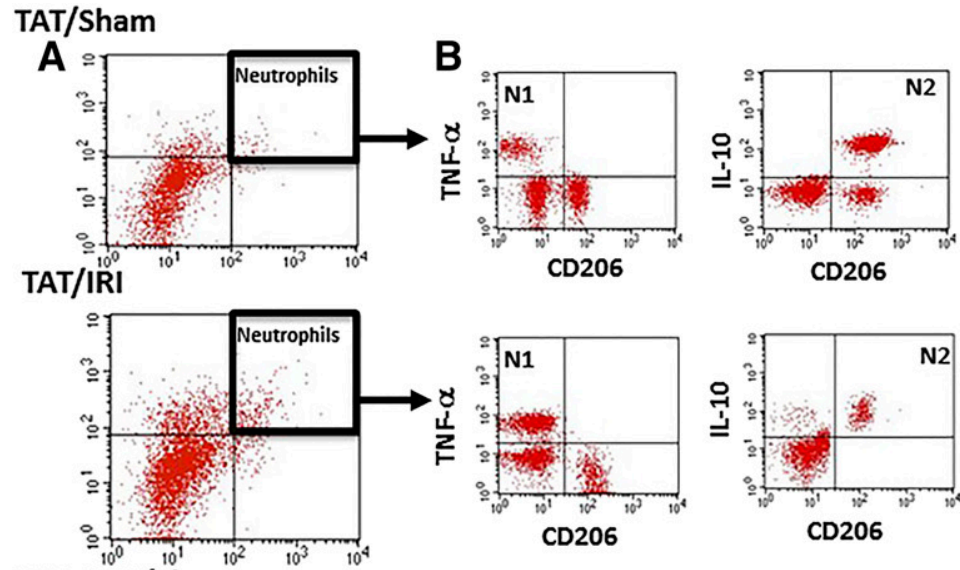

TAT-GILZ/Sham

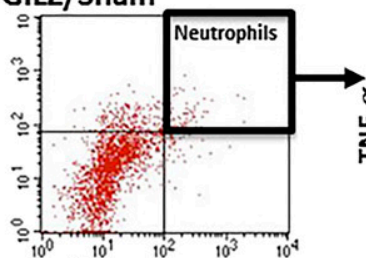

TAT-GILZ/IRI

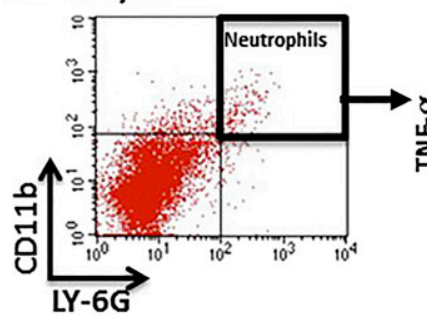

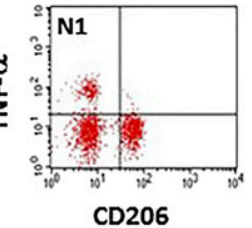
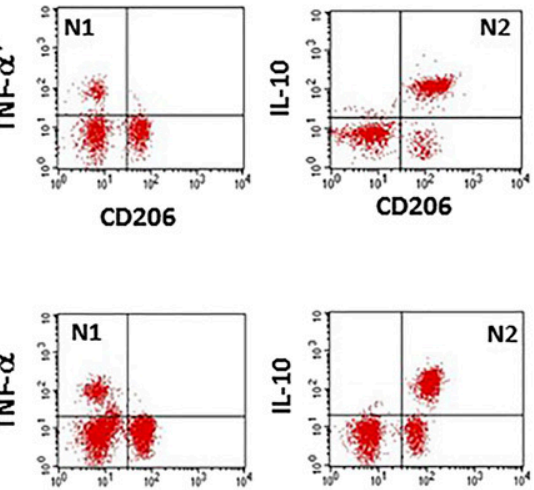

CD206

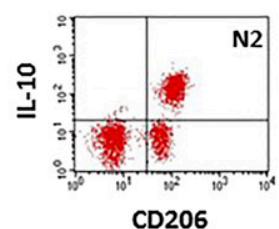

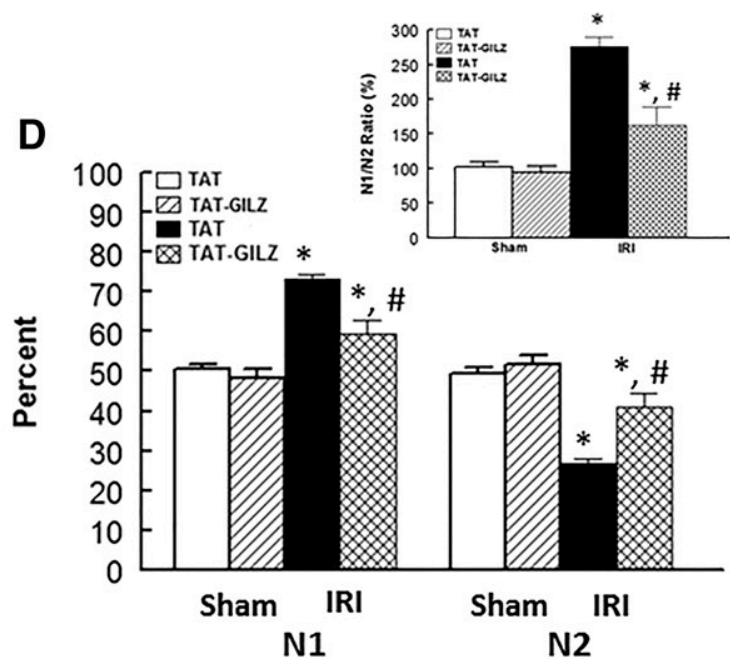
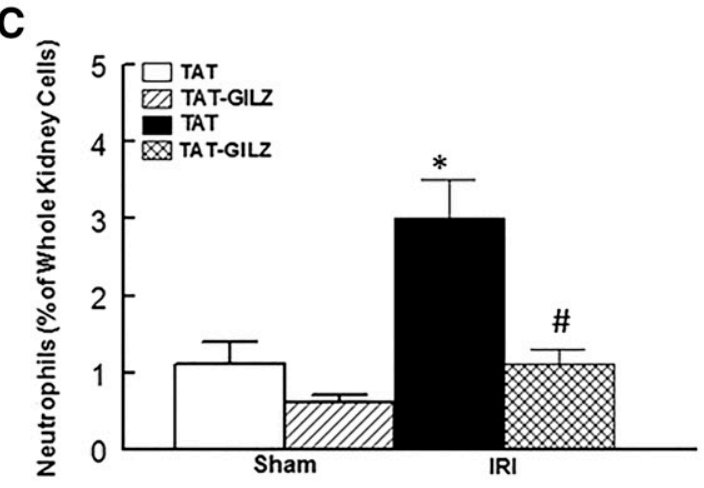

Fig. 1. Effects of renal IRI and GILZ delivery on neutrophil polarization. Cells were prepared from renal tissues of TAT-treated and TAT-GILZ-treated mice subjected to left kidney IRI and right kidney sham operation, as described in Materials and Methods. Thereafter, using flow cytometry-based studies, neutrophils were initially identified as Ly- $6 \mathrm{G}^{+} / \mathrm{CD} 11 \mathrm{~b}^{+}$cells based on the expression or lack thereof of CD206 [(A) dot plots] (Materials and Methods) followed by functional assessment based on the production of TNF- $\alpha$ as N1 (proinflammatory neutrophils) or the production of IL-10 as N2 (regulatory neutrophils), as shown on representative dot matrices in (B). In (C), the bar graph shows total neutrophils, expressed as a percentage of total kidney cells, whereas (D) shows N1 and N2, as a percentage of neutrophils, for kidneys of experimental groups; the inset in (D) shows the N1/N2 ratio for experimental groups. Data are average \pm S.E.M. of $n=5$ kidneys/condition. $* P<0.05$ compared with their sham-operated counterparts. \#P<0.05 compared with their TAT-treated counterparts.

cells compared with their sham-operated counterparts; however, TAT-GILZ-treated ischemic-reperfused kidneys showed significantly reduced frequency of IL- $17^{+}$cells compared with their TAT-treated counterparts (Fig. 3A). On the other hand, TAT-treated or TAT-GILZ-treated ischemic-reperfused kidneys displayed a significantly lower frequency of IL- $10^{+}$cells compared with their sham-operated counterparts, but the reduction was less for the TAT-GILZ-treated group. As a result, TAT-GILZ-treated kidneys subjected to IRI displayed a higher frequency of IL- $10^{+}$cells compared with their TATtreated counterparts (Fig. 3B).

Cytoprotective Effects of TAT-GILZ in AKI. We next assessed apoptotic/necrotic cell death in whole-kidney cell preparations, using 7-aminoactinomycin D/caspase-3 assay, in the context of the assessment of $\psi_{\mathrm{m}}$ using the JC-1 ( $5,5^{\prime}, 6,6^{\prime}$-tetrachloro-1,1',3,3'-tetraethylbenzimidazolylcarbocyanine iodide) assay. The JC-1 assay identifies the relative proportion of JC aggregates and monomers; a low ratio of JC aggregate/monomer is indicative of injured/damaged cells (Fig. 4, A and C). On the other hand, Fig. 4B shows representative dot matrices depicting early apoptotic, late apoptotic, and necrotic cells in a whole-kidney cell preparation of experimental animals. Figure 4A shows flow cytometry histograms depicting high-JC aggregates (but low monomers) for sham kidney cells of TAT and TAT-GILZ mice, whereas the cells of kidneys from TAT-treated mice subjected to IRI show increased JC monomers (but low aggregates) with the pattern reversing to those of sham animals in TAT-GILZ-treated mice whose kidneys were subjected to IRI. Consistent with these observations, shamoperated animals treated with TAT or TAT-GILZ displayed similar aggregates/monomer ratios in their kidney cells preparations (Fig. 4C). On the other hand, kidney cells prepared from TAT-treated mice subjected to IRI showed significant reduction in JC aggregates/monomers ratio, an effect partially reversed by TAT-GILZ treatment (Fig. 4C). Consistent with these observations, kidney apoptotic/necrotic cell death was significantly higher in TAT-treated IRI mice compared with sham-operated animals; treatment with TAT-GILZ reduced kidney cell death in animals subjected to renal IRI, although a differential persisted between those subjected to IRI and their sham-operated counterparts (Fig. 4D).

TAT-GILZ Regulates Neutrophil and T-Cell Cross Talk. To determine whether GILZ regulates the interaction between neutrophils and $\mathrm{T}$ cells, we used a "reductionist 
A

TAT/Sham

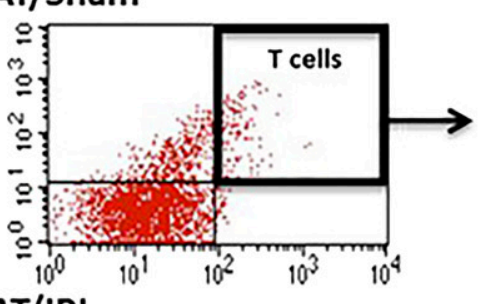

TAT/IRI

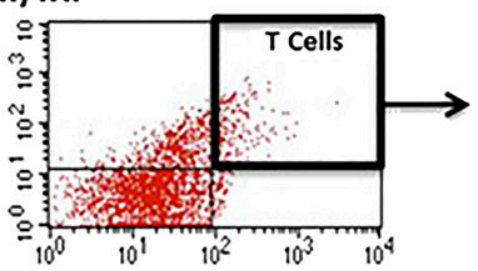

TAT-GILZ/Sham

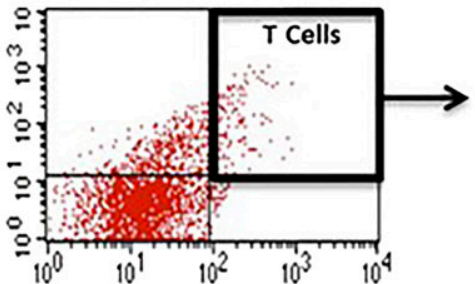

TAT-GILZ/IRI

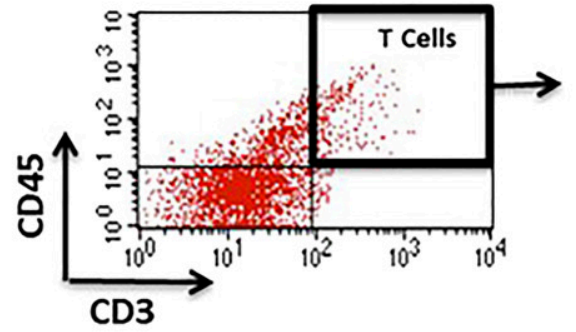

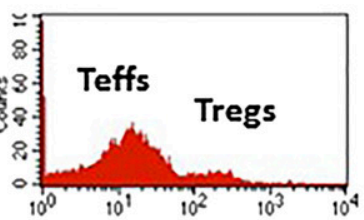

CD45+/CD3+/FOXP3+
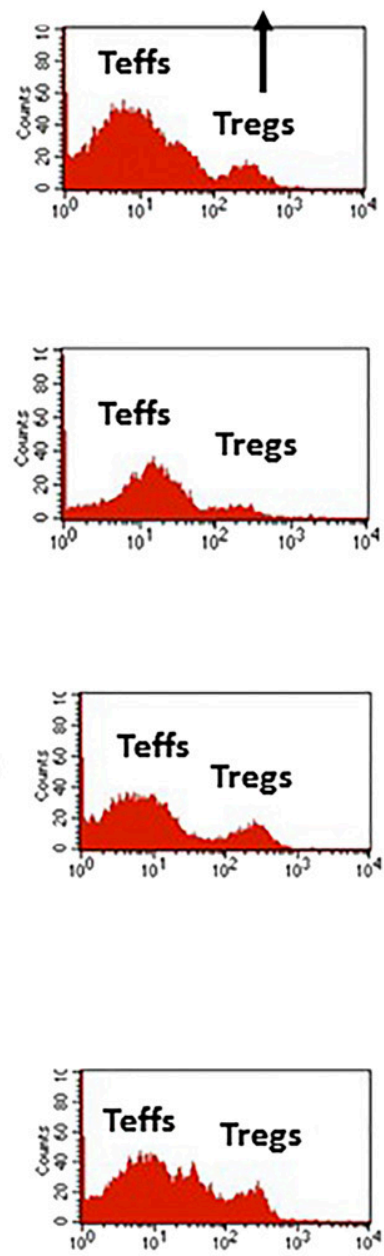

FOXP3
B

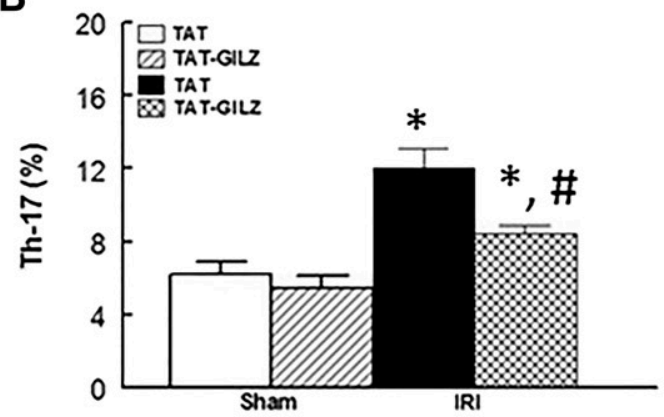

C

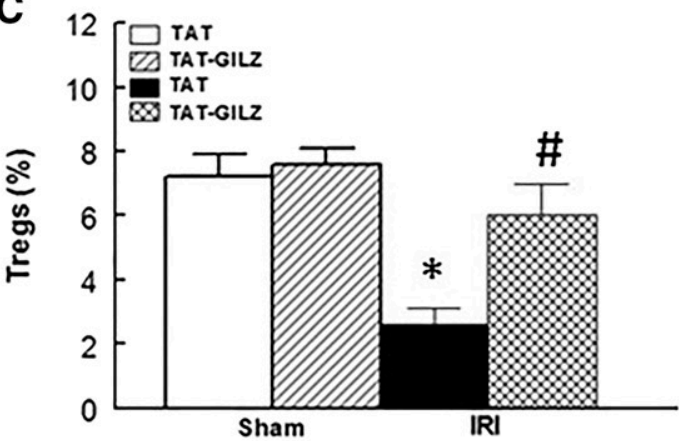

D 3 T TAT

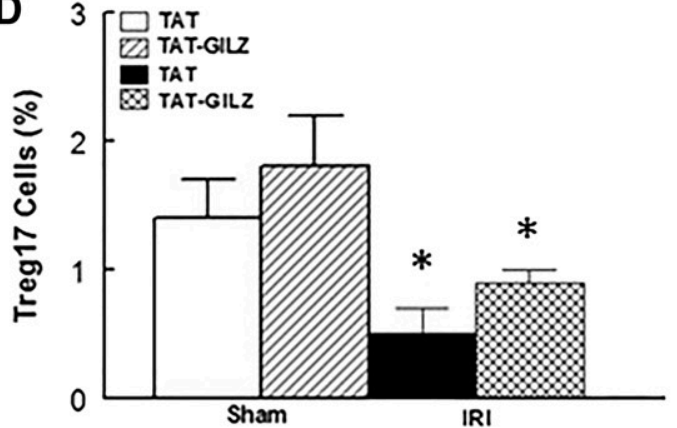

Fig. 2. Effects of renal IRI and GILZ delivery on T-cell polarization. Cells were prepared from renal tissues of TAT-treated and TAT-GILZ-treated mice subjected to left kidney IRI and right kidney sham operation as described in Materials and Methods. (A) Thereafter, using flow cytometry-based studies, we initially identified Teffs $\left(\mathrm{CD} 45^{+} / \mathrm{CD}^{+}\right)$and Tregs $\left(\mathrm{CD} 45^{+} / \mathrm{CD} 3^{+} / \mathrm{FOXP}^{+}\right)$. This was followed by the further identification of Th-17 lymphocytes as IL-17-producing Th cells (CD45 $\left./ \mathrm{CD}^{+} / \mathrm{IL}-17^{+}\right)$. On the other hand, Tregs were further assessed for the expression of CD196 (CCR6) and STAT3 to identify Treg 17 cells (i.e., CD $\left.45^{+} / \mathrm{CD}^{+} / \mathrm{FOXP}^{+} / \mathrm{CCR}^{+} / \mathrm{STAT}^{+}\right)$. Bar graphs show Th-17 cells (B), Tregs (C), and Treg17 cells (D) expressed as a percentage of total T lymphocytes for experimental groups. Data are the average \pm S.E.M. of $n=5$ mice/group. $* P<0.05$ compared with their shamoperated counterparts. $\# P<0.05$ compared with their TAT-treated counterparts.

system": the MLR assay. As shown in Fig. 5, T cells and neutrophils that were coincubated under the control condition or treated with TAT displayed stimulation and marked increase in Th cell proliferation. By contrast, treatment of coincubated $\mathrm{T}$ cells and neutrophils with
TAT-GILZ markedly suppressed the proliferation of Th cells.

TAT-GILZ Increases Renal Perfusion but Reduces Tissue Edema. In light of the cytoprotective effect of TATGILZ in the murine model of AKI, we next examined whether
A

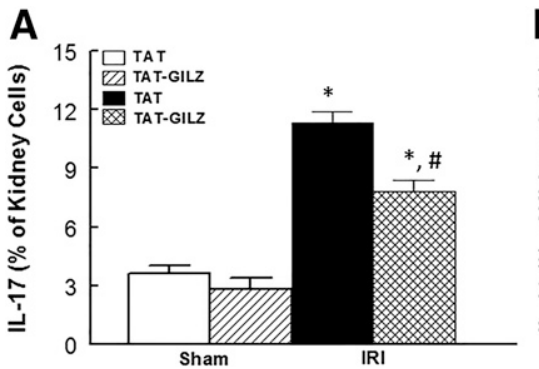

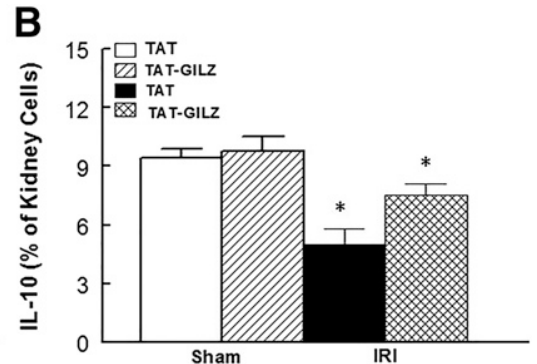

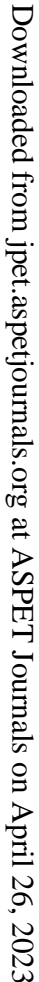

Fig. 3. Effects of renal IRI and GILZ delivery on IL-17 ${ }^{+}$ and IL- $10^{+}$cells. Bar graphs show the percentage of IL- $17^{+}(\mathrm{A})$ and IL- $10^{+}(\mathrm{B})$ cells in kidney cell preparations of experimental groups. Data are the average \pm S.E. M. of $n=5$ mice/group. $* P<0.05$ compared with their sham-operated counterparts. $\# P<0.05$ compared with their TAT-treated counterparts. 

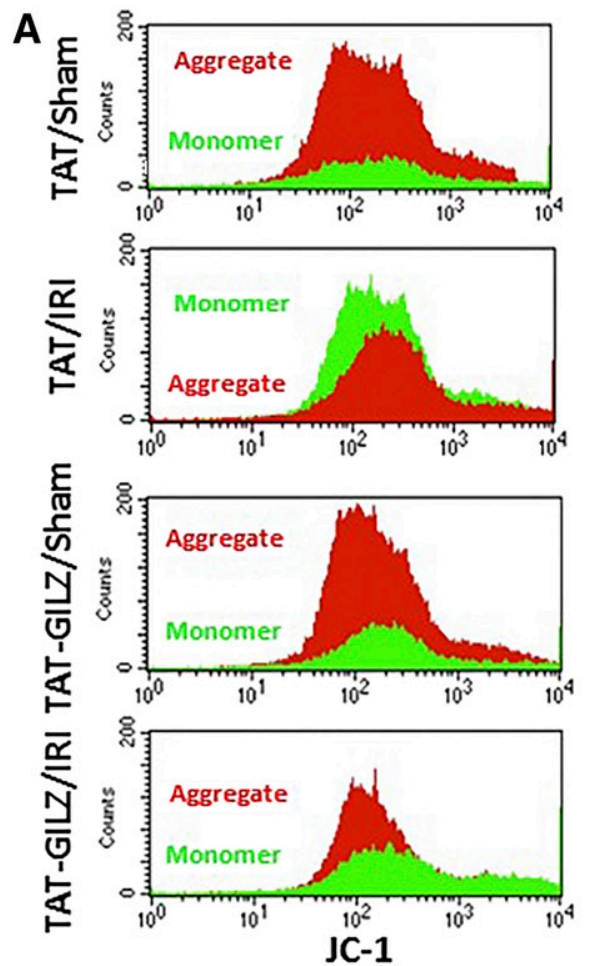
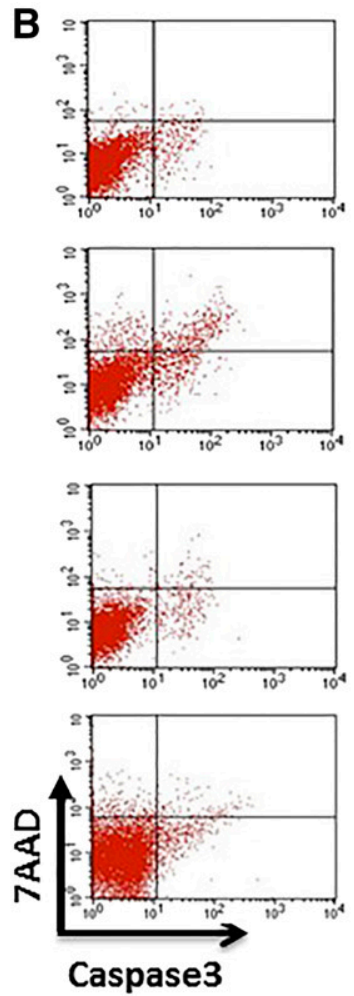
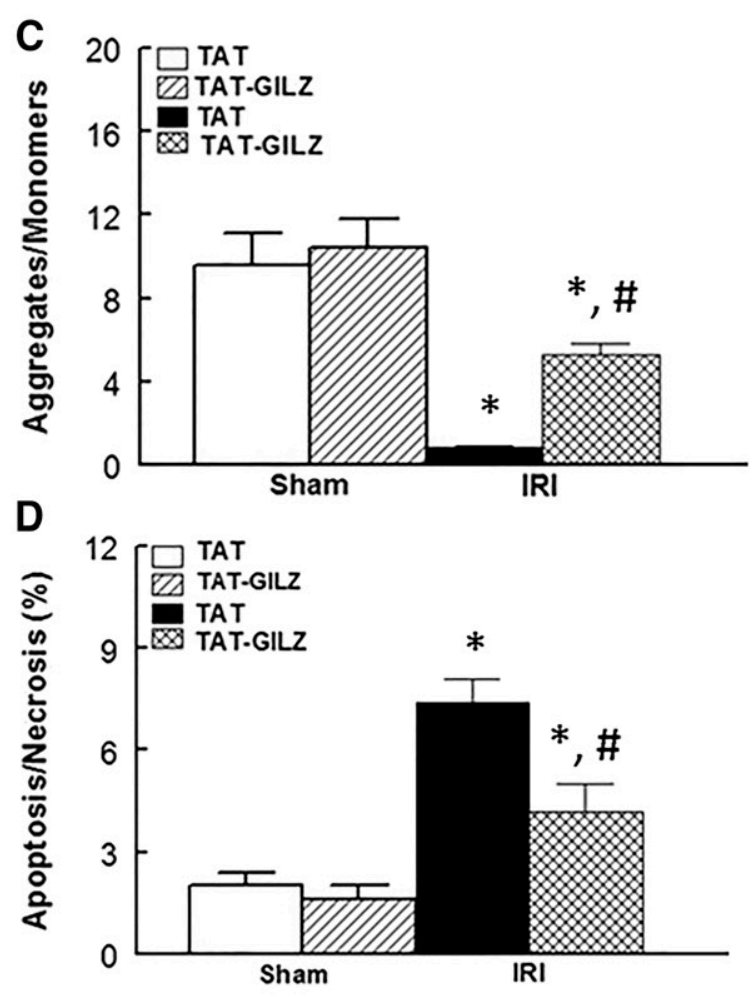

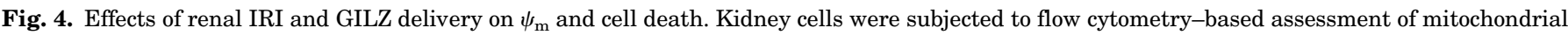

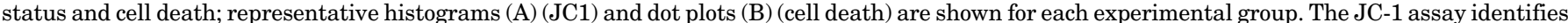

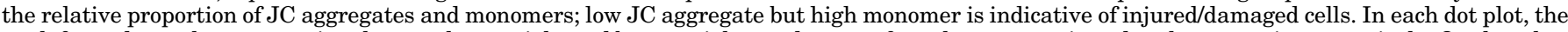

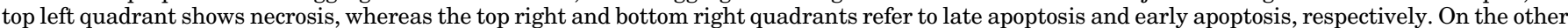

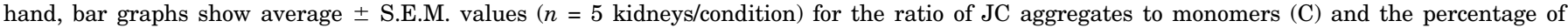

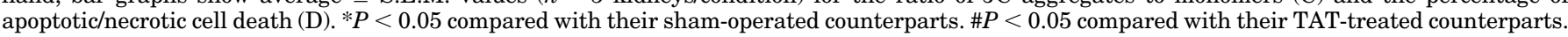

the treatment affects kidney function. These studies used multiparametric MRI to assess the indices of renal perfusion and tissue edema (Hueper et al., 2016). As shown in Fig. 6, TAT-treated animals displayed similar ratio of left kidney (ischemic-reperfused) to right kidney (sham) perfusion 1 and 5 days after treatment with TAT. On the other hand, animals treated with TAT-GILZ showed a significant increase in this ratio in progression from day 1 to day 5 post-IRI compared with their TAT-treated counterparts, which is suggestive of improved perfusion of ischemic-reperfused kidney. Figure 7 shows representative $\mathrm{T} 2$ maps and $\mathrm{T} 2$ relaxation times (Fig. 7 , A and B), whereas Fig. 7, C and D, shows kidney weight and kidney size, respectively, for the experimental groups; the inset to Fig. 7C shows photos of kidneys for one animal in each group. Cortical and medullary T2 relaxation times were significantly reduced in TAT-GILZ-treated versus TAT-treated ischemicreperfused kidneys, at day 5 postinjury, which is suggestive of reduced renal tissue edema in the former compared with the latter group. Figure 7, C and D shows that whereas the right kidney (sham) weight and size were higher than those of the left kidney (IRI) of TAT-treated animals $(P<0.05)$, the right and left kidney weight and size were similar for TATGILZ-treated animals and lower than those of the right kidney of TAT-treated group $(P<0.05)$.

\section{Discussion}

We show that TAT-GILZ treatment resulted in cytoprotection, in the murine model of AKI, accompanied by decreased
N1s and Th-17 cells but increased N2s and Tregs. The treatment also decreased $\mathrm{IL}-17^{+}$cells but increased IL-10 ${ }^{+}$ cells in the kidney subjected to IRI. Further, TAT-GILZ treatment improved tissue perfusion but reduced cortical and medullary tissue edema as well as the size and weight of ischemic-reperfused kidneys compared with TAT treatment. These novel observations indicate that TAT-GILZ regulates the development of suppressive phenotypes of neutrophils and $\mathrm{T}$ cells, likely contributing to its renoprotective effect.

As archetypal cells of the innate immunity, neutrophils are the most abundant leukocytes in the circulation and are recruited very early, usually within 30 minutes, to the kidney subjected to IRI; they are key effectors of the inflammatory cascade through their functional properties, which include the generation of reactive oxygen and nitrogen species, chemotaxis, and phagocytosis (Lauriat and Linas, 1998; Jang and Rabb, 2009; Iwashima and Love, 2013; Kourtzelis et al., 2017; Ricci et al., 2017). In the absence of inflammatory signals, neutrophils die via spontaneous apoptosis. However, upon stimulation by an inflamed endothelium, which prevails in the ischemic-reperfused kidney, neutrophils are activated via five distinct phases: tethering, rolling, adhesion, crawling, and transmigration into the interstitium (Ricci et al., 2017). Indeed, consistent with our observations, increased neutrophils in the kidney has been described for both animal models and kidney biopsy samples from patients with AKI (Bolisetty and Agarwal, 2009). Consequences of the dysregulation of neutrophils in AKI include the release of proteases and myeloperoxidases, and the generation of reactive oxygen and 

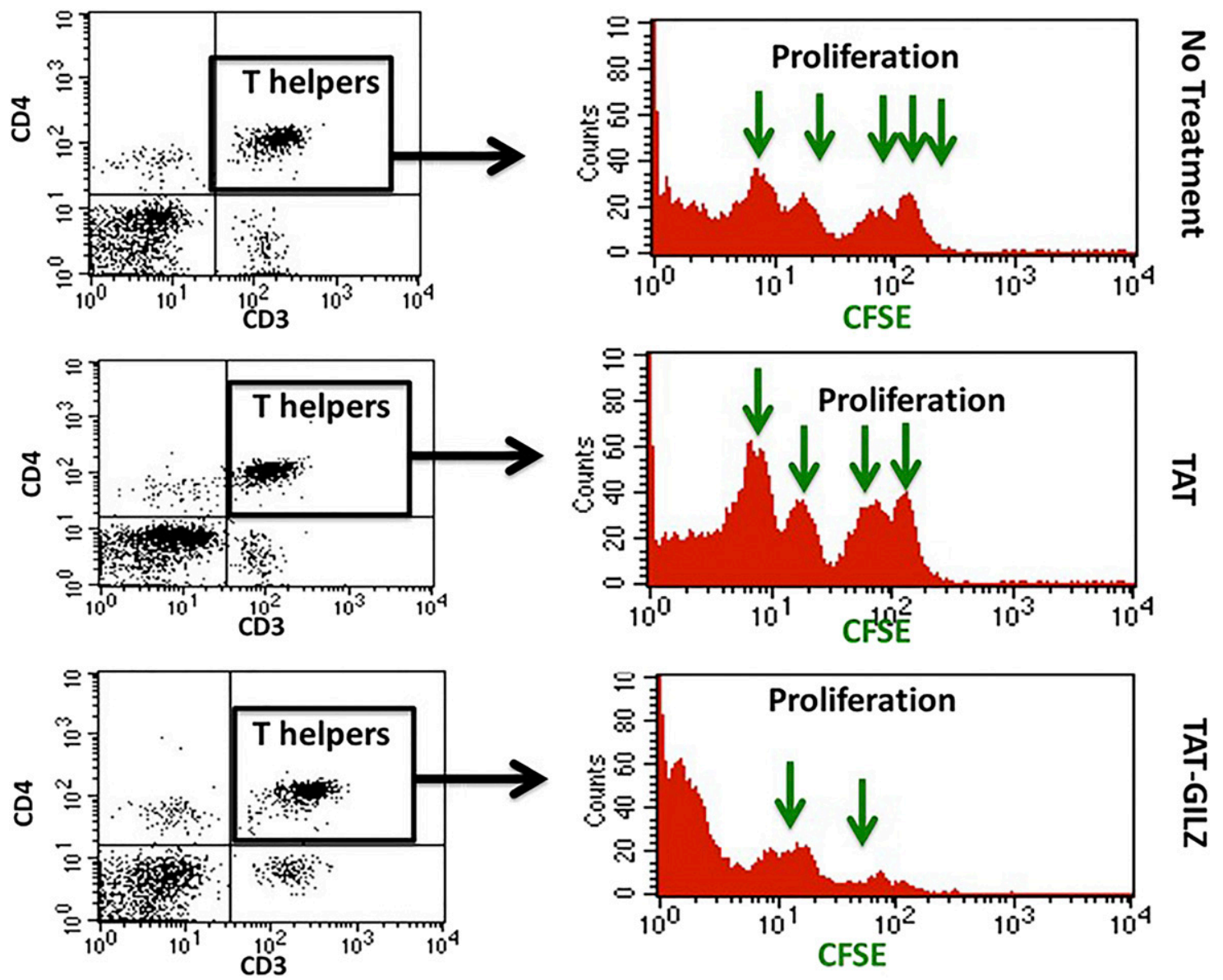

Fig. 5. Effect of TAT-GILZ on cross talk between T cells and neutrophils. Flow cytometry panels show the results of the MLR assay indicating marked reduction in Th cell proliferation in response to treatment with TAT-GILZ compared with treatment with TAT or under control conditions, as described in Materials and Methods.

nitrogen species that can aggravate injury and damage endothelial and epithelial cells (Bolisetty and Agarwal, 2009). Thus, should neutrophils not be cleared from sites of injury, they can promote further inflammation and exacerbate tissue injury. In this context, it is shown that the depletion or inhibition of neutrophil accumulation in the ischemicreperfused kidney prevents AKI (Jang and Rabb, 2009). Further, strategies to block endothelial-neutrophil interactions (e.g., antibodies targeting adhesion molecules) exert cytoprotection in animal models of AKI (Lauriat and Linas, 1998).
On the other hand, others (Thornton et al., 1989; Melnikov et al., 2002) have reported that significant neutrophil accumulation does not occur during ischemia-reperfusion and that neutrophil depletion does not protect from AKI. The reasons for such disparate findings are not clear because the role of neutrophils, given their abundance in the circulation, in any inflammatory response is undeniable. It is likely that varied observations relate to the timing of the assessment, given the temporal changes in infiltration of immune cells into the injured kidney. Our observations clearly indicate increased
A Day 1
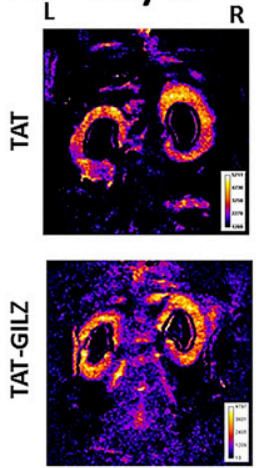

Day 5

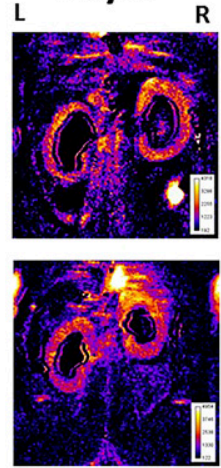

B

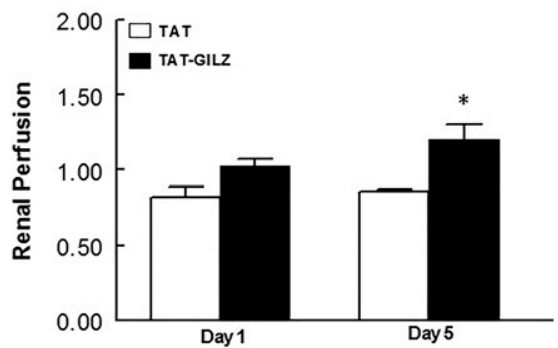

Fig. 6. Effect of TAT-GILZ on renal perfusion. (A) Representative flow-sensitive alternating inversion recovery images. (B) Renal perfusion for experimental animals ( $n$ $=3 \mathrm{mice} /$ group/condition) expressed as the ratio of left kidney to right kidney perfusion for each animal on each day as described in Materials and Methods. ${ }^{*} P<0.05$ compared with their TAT counterparts. 
A
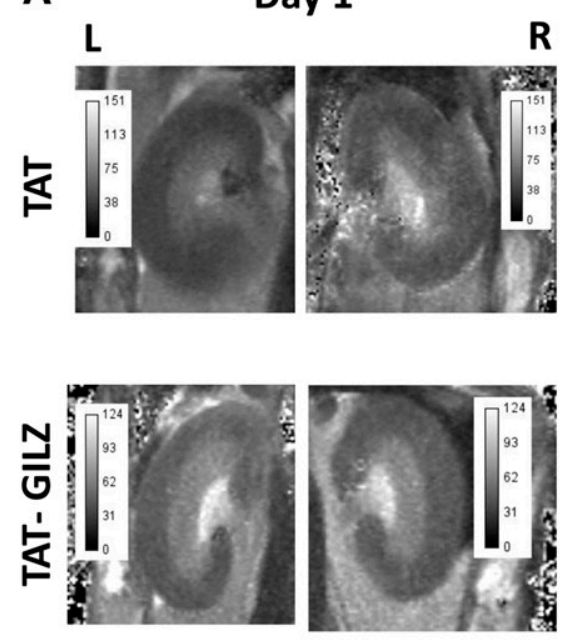

B

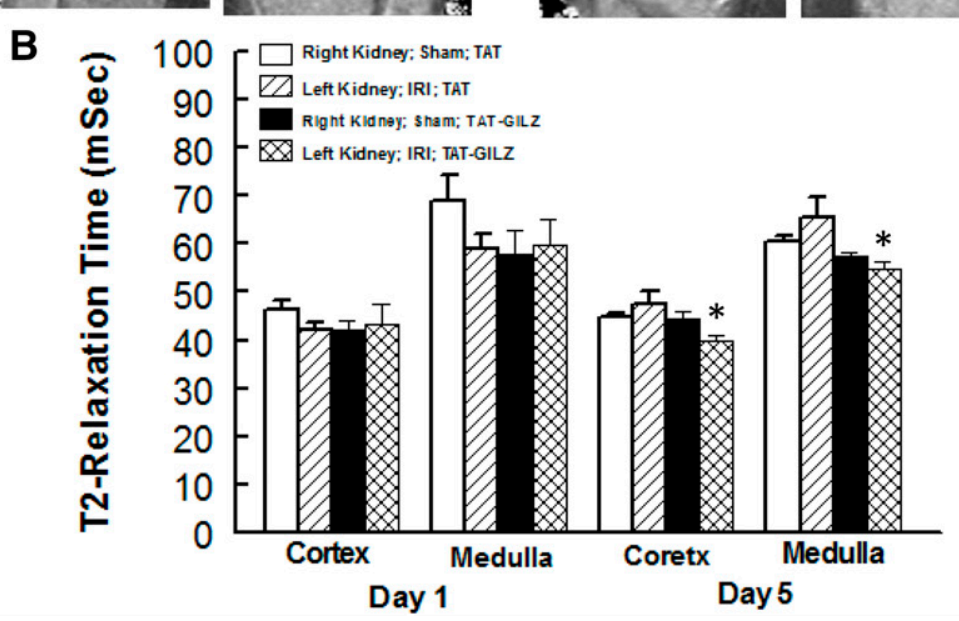

$\mathbf{R}$
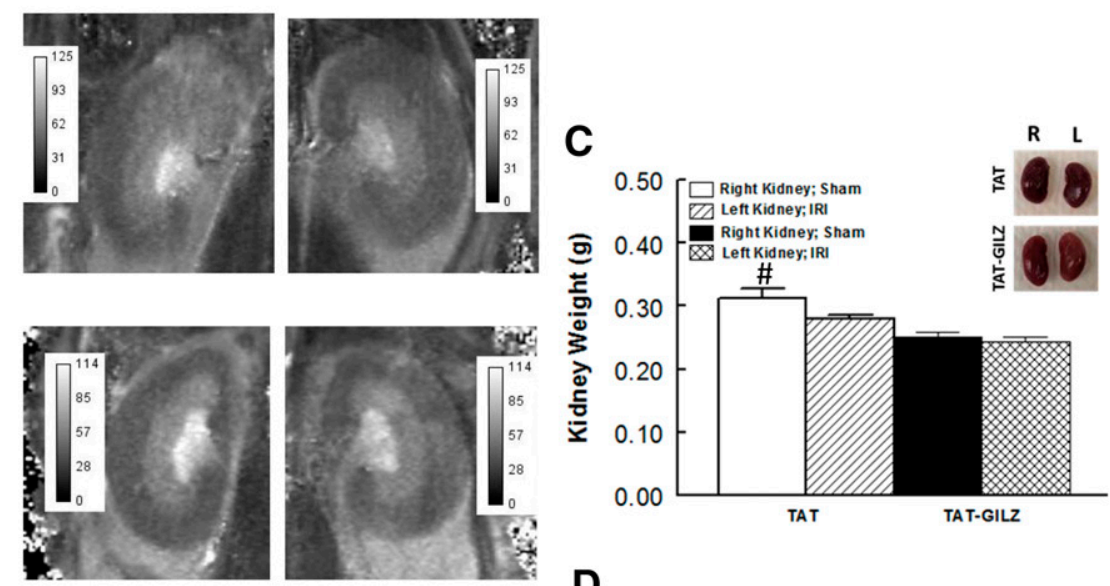

D

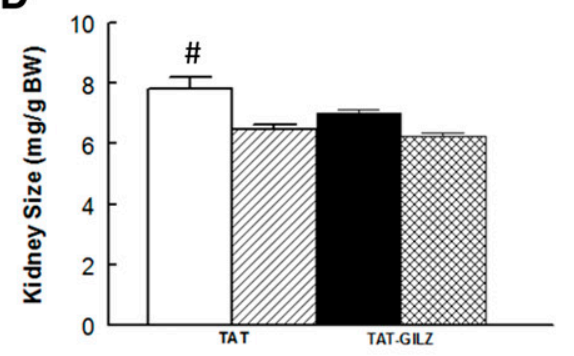

proinflammatory, N1, phenotype but reduced anti-inflammatory, N2, phenotype in the ischemic-reperfused kidney. Importantly, treatment with TAT-GILZ significantly reduced the total number of infiltrating neutrophils and also restored, albeit partially, the N1/N2 imbalance accompanied with preservation of functional status of N2s (i.e., IL-10 ${ }^{+}$) in the kidney subjected to IRI. To our knowledge, this is the first demonstration of the impact of TAT-GILZ treatment on neutrophil polarization, although a recent report (Ricci et al., 2017) implicates GILZ in the regulation of neutrophil migration in peritonitis via regulating the expression of annexin A1, a protein known for resolving the inflammatory response. Collectively, these observations raise the possibility of cross talk between GILZ and annexin A1 in regulating neutrophil polarization in favor of $\mathrm{N} 2$, aspects that remain to be established.

Aside from neutrophils, T lymphocytes are also intimately involved in the response to renal IRI. This is evident from the demonstration that mice deficient in $\mathrm{CD}^{+}$(and $\mathrm{CD}^{+}$) $\mathrm{T}$ lymphocytes exhibit diminished renal injury after IRI (Rabb et al., 2000) and that adoptive transfer of $\mathrm{T}$ cells to athymic mice confers AKI (Burne et al., 2001). Among the subtypes of Teffs, Th-1 and Th-2 cells are known to contribute to the pathogenesis of AKI; Th-1 produces proinflammatory cytokines (e.g., interferon- $\gamma$ and IL-2), whereas Th-2 secret anti-inflammatory cytokines (e.g., IL-4 and IL-10). Both Th-1 and Th-2 cells are believed to be involved in the early phase post-IRI. In addition, there is evidence that $\mathrm{CD}^{+}$(and $\mathrm{CD}^{+}$) cells are also present in the recovery phase post-IRI and likely play a pathogenic role in the progression from AKI to chronic kidney injury. Indeed, the prevalence of the Th-1 phenotype is a feature of delayed graft function in renal transplant patients (Wang et al., 2008; Ascon et al., 2009; Bonavia and Singbartl, 2018). Aside from Th-1 and Th- 2 cells, Th-17 cells are also implicated in the pathogenesis of AKI (Guo et al., 2016). On the other hand, Tregs can directly suppress the activation and proliferation of $\mathrm{T}$ cells and can even induce apoptosis via the secretion of anti-inflammatory cytokines such as IL-10, IL-35, and transforming growth factor- $\beta$. In models of AKI, Tregs attenuate the initial phase of injury while promoting repair, but the depletion of Tregs (via anti-CD25 monoclonal antibody) exacerbates renal tubular damage, reduces tubular proliferation, and increases proinflammatory cytokine production (Kinsey et al., 2009). We show a marked increase in Th-17 cells but a marked decrease in Tregs in kidneys subjected to IRI. Importantly, however, treatment with TAT-GILZ 
reversed this pattern, as evidenced by the significant reduction in Th-17 cells while increasing Tregs; similar changes were observed for IL- $17^{+}$and IL- $10^{+}$cells in whole-kidney cell preparations. Our observations are consistent with those from previous reports indicating that GILZ promotes the production of peripheral Tregs in vivo; indeed, GILZ is required for glucocorticoid-induced upregulation of FOXP3 (forkhead box P3) expression and the increase in Tregs (Bereshchenko et al., 2014). Interestingly, however, TAT-GILZ treatment did not significantly affect Treg 17 cells under the conditions of this study. The reason for this observation is not clear but likely relates to the requirement of signal transducer and activator of transcription 3 (STAT3) transcription factor activity for the development and functional activity of Treg 17 cells (Chaudhry et al., 2009; Kluger et al., 2016). GILZ expression is shown to negatively correlate with STAT3 expression in lesional skin of psoriatic patients (Jones et al., 2015). Further, glucocorticoid receptor tethering to DNA-bound STAT3 causes transcription repression (Ratman et al., 2013). Thus, it remains to be determined whether GILZ impacts STAT3 in the context of the development and functional activity of Treg17 cells.

The profound impact of renal IRI on N1s and Th17 cells was accompanied by marked disruption of $\psi_{\mathrm{m}}$, as indexed by a reduction in the ratio of JC aggregates/monomers, and by a significant increase in apoptotic/necrotic cell death. Consistent with its anti-inflammatory properties, TAT-GILZ treatment was accompanied by significant, albeit partial, preservation of $\psi_{\mathrm{m}}$ and reduction of cell death. These observation are consistent with those of our recent study (Baban et al., 2017), whereby intramyocardial treatment with GILZ-overexpressing mesenchymal stem cells exerted significant cardioprotection. Others (Aguilar et al., 2014) have shown that GILZ overexpression protects against doxorubicin-induced cardiomyopathy, as exemplified by the induction of prosurvival protein Bcl-xL, the prevention of mitochondrial release of cytochrome $c$, and the cleavage of caspase-3. Similarly, GILZ overexpression protects against endoplasmic reticulum stress-mediated cell death, likely via the stimulation of mitochondrial oxidative phosphorylation (André et al., 2016). Further, the overexpression of GILZ is protective of the retina against light-induced cellular damage via the activation of antiapoptotic pathways (Gu et al., 2017). Despite the reported prosurvival and cytoprotective effects of GILZ, a recent report (Espinasse et al., 2016) indicates that GILZ overexpression in PLB-985 cells (which can differentiate into mature neutrophils) exacerbates apoptosis in association with the activation of caspase- 9 and caspase-3 as well as the loss of mitochondrial potential. Collectively, these studies indicate context- and cell-specific effects of GILZ with respect to the mitochondrial death pathway.

Given the cytoprotective effects of TAT-GILZ treatment on AKI, we next determined whether the treatment beneficially affects indices of renal function. Indeed, utilizing functional MRI, we demonstrated that TAT-GILZ treatment improves tissue perfusion in the ischemic-reperfused kidney in association with reduction in cortical and medullary tissue edema. Interestingly, left (ischemic-reperfused) and right (sham) kidney weight and size were similar for TAT-GILZ-treated mice, whereas the right kidney weight and size in TAT-treated animals were significantly greater than those of their left kidneys. Collectively, the data suggest that functional hypertrophy may underlie the larger right kidney size and weight of TAT-treated animals to compensate for the injury sustained by the left kidney that was subjected to IRI. Thus, it is likely that TAT-GILZ-induced protective effects preclude/attenuate the need to maintain the functional hypertrophy of the undamaged/sham kidney. Our observation that TAT-GILZ treatment exerts renoprotective effects after renal IRI would be expected to limit chronic kidney injury, a potential sequel of AKI.

In light of our observations with the murine model of AKI, we further explored whether GILZ regulates cross talk between neutrophils and $\mathrm{T}$ cells, given their pivotal roles in the pathogenesis of this condition. Activated neutrophils are known to directly or indirectly regulate T-cell activations via a number of suppressive (e.g., reactive oxygen species, arginase-1, IL-10) and stimulatory (e.g., several chemokines, IL-12, neutrophil extracellular traps) pathways (Kalyan and Kabelitz, 2014). In addition, neutrophils are believed to transport antigens to sites of T-cell activation and even to act as antigen-presenting cells (Maletto et al., 2006; Abi Abdallah et al., 2011; Duffy et al., 2012). These observations provided us with the rationale to use bone marrow-derived neutrophils as antigen-presenting cells while splenic $\mathrm{T}$ cells served as responder cells in the MLR assay. This was intended as an initial attempt to explore whether GILZ regulates the interaction of neutrophils and T cells. Indeed, we observed a marked increase in the proliferation of $\mathrm{T}$ cells upon coincubation with neutrophils, an effect that persisted with TAT treatment. Importantly, however, the inclusion of TAT-GILZ in the MLR assay mixture resulted in the marked suppression of T-cell proliferation, providing strong evidence in support of GILZ-induced regulation of cross talk between neutrophils and $\mathrm{T}$ cells. One likely mechanism may involve the GILZinduced promotion of regulatory/suppressive neutrophils, N2, which are known to produce IL-10, which subsequently suppresses Th cell proliferation. Indeed, neutrophils are shown to exert differential suppressive activity on Th-1 versus Th-17 cells, in vivo, with selective inhibition of Th-17 cells in an IL-10-dependent fashion (Yang and Unanue, 2013).

In conclusion, our results suggest pathogenic roles for neutrophil polarization and Th-17/Treg imbalance in AKI. Importantly, TAT-GILZ treatment favored the development of regulatory/suppressive phenotypes of neutrophils (i.e., N2) and $\mathrm{T}$ cells (i.e., Tregs) in association with significant renoprotection, as revealed by preservation of mitochondrial function, reduction in kidney cell death, improvement in renal tissue perfusion, and reduction in kidney edema. Although a prevalent condition with significant morbidity and mortality, the therapeutic options are limited for AKI. Importantly, AKI predisposes those who survive the acute episode to increased risk for chronic renal failure. Thus, therapeutic GILZ may offer an effective option to limit tissue injury, given its ability to favor the suppressive/regulatory arm of immunity, reduce inflammation, and improve functional outcome.

\section{Acknowledgments}

We thank Roxan Ara, of Core Imaging Facility for Small Animals, for assistance with the magnetic resonance imaging.

\section{Authorship Contributions}

Participated in research design: Baban, Arbab, Mozaffari. Conducted experiments: Baban, Khodadadi, Malik, Emami, Lin, Mozaffari.

Contributed new reagents or analytic tools: Marchetti, Riccardi. Performed data analysis: Baban, Khodadadi, Mozaffari. 
Wrote or contributed to the writing of the manuscript: Baban, Arbab, Riccardi, Mozaffari.

\section{References}

Abi Abdallah DS, Egan CE, Butcher BA, and Denkers EY (2011) Mouse neutrophils are professional antigen-presenting cells programmed to instruct Th1 and Th17 T-cell differentiation. Int Immunol 23:317-326.

Aguilar D, Strom J, and Chen QM (2014) Glucocorticoid induced leucine zipper inhibits apoptosis of cardiomyocytes by doxorubicin. Toxicol Appl Pharmacol 276 $55-62$.

André F, Corazao-Rozas P, Idziorek T, Quesnel B, Kluza J, and Marchetti P (2016) GILZ overexpression attenuates endoplasmic reticulum stress-mediated cell death via the activation of mitochondrial oxidative phosphorylation. Biochem Biophys Res Commun 478:513-520.

Ascon M, Ascon DB, Liu M, Cheadle C, Sarkar C, Racusen L, Hassoun HT, and Rabb $H$ (2009) Renal ischemia-reperfusion leads to long term infiltration of activated and effector-memory T lymphocytes. Kidney Int 75:526-535.

Ayroldi E and Riccardi C (2009) Glucocorticoid-induced leucine zipper (GILZ): a new important mediator of glucocorticoid action. FASEB J 23:3649-3658.

Baban B, Chandler PR, Sharma MD, Pihkala J, Koni PA, Munn DH, and Mellor AL (2009) IDO activates regulatory T cells and blocks their conversion into Th17-like T cells. J Immunol 183:2475-2483.

Baban B, Hoda MN, Malik A, Khodadadi H, Simmerman E, Vaibhav K and Mozaffari MS (2018) The impact of cannabidiol treatment on regulatory T-17 cells and neutrophil polarization in acute kidney injury. Am $J$ Physiol Renal Physiol 315:F1149-F1158. DOI:10.1152/ajprenal.00112.2018 [published ahead of print].

Baban B, Liu JY, and Mozaffari MS (2012) Aryl hydrocarbon receptor agonist, leflunomide, protects the ischemic-reperfused kidney: role of Tregs and stem cells. Am J Physiol Regul Integr Comp Physiol 303:R1136-R1146.

Baban B, Yin L, Qin X, Liu JY, Shi X, and Mozaffari MS (2017) The role of GILZ in modulation of adaptive immunity in a murine model of myocardial infarction. Exp Mol Pathol 102:408-414.

Beaulieu E, Ngo D, Santos L, Yang YH, Smith M, Jorgensen C, Escriou V, Scherman D, Courties G, Apparailly F, et al. (2010) Glucocorticoid-induced leucine zipper is an endogenous antiinflammatory mediator in arthritis. Arthritis Rheum 62 2651-2661.

Bereshchenko O, Coppo M, Bruscoli S, Biagioli M, Cimino M, Frammartino T, Sorcini D, Venanzi A, Di Sante M, and Riccardi C (2014) GILZ promotes production of peripherally induced Treg cells and mediates the crosstalk between glucocorticoids and TGF- $\beta$ signaling. Cell Rep 7:464-475.

Bolisetty S and Agarwal A (2009) Neutrophils in acute kidney injury: not neutral any more. Kidney Int 75:674-676.

Bonavia A and Singbartl K (2018) A review of the role of immune cells in acute kidney injury. Pediatr Nephrol 33:1629-1639.

Burne MJ, Daniels F, El Ghandour A, Mauiyyedi S, Colvin RB, O'Donnell MP, and Rabb H (2001) Identification of the CD4(+) $\mathrm{T}$ cell as a major pathogenic factor in ischemic acute renal failure. J Clin Invest 108:1283-1290.

Cannarile L, Cuzzocrea S, Santucci L, Agostini M, Mazzon E, Esposito E, Muià C, Coppo M, Di Paola R, and Riccardi C (2009) Glucocorticoid-induced leucine zipper is protective in Th1-mediated models of colitis. Gastroenterology $\mathbf{1 3 6}$ $530-541$

Cannarile L, Zollo O, D’Adamio F, Ayroldi E, Marchetti C, Tabilio A, Bruscoli S, and Riccardi C (2001) Cloning, chromosomal assignment and tissue distribution of human GILZ, a glucocorticoid hormone-induced gene. Cell Death Differ 8:201-203.

Chaudhry A, Rudra D, Treuting P, Samstein RM, Liang Y, Kas A, and Rudensky AY (2009) CD4+ regulatory T cells control TH17 responses in a Stat3-dependent manner. Science 326:986-991.

D’Adamio F, Zollo O, Moraca R, Ayroldi E, Bruscoli S, Bartoli A, Cannarile L, Migliorati G, and Riccardi C (1997) A new dexamethasone-induced gene of the leucine zipper family protects $\mathrm{T}$ lymphocytes from TCR/CD3-activated cell death. Immunity 7:803-812.

Denecke C and Tullius SG (2014) Innate and adaptive immune responses subsequent to ischemia-reperfusion injury in the kidney. Prog Urol 24 (Suppl 1):S13-S19.

Duffy D, Perrin H, Abadie V, Benhabiles N, Boissonnas A, Liard C, Descours B, Reboulleau D, Bonduelle O, Verrier B, et al. (2012) Neutrophils transport antigen from the dermis to the bone marrow, initiating a source of memory CD8+ T cells. Immunity 37:917-929

Espinasse MA, Pépin A, Virault-Rocroy P, Szely N, Chollet-Martin S, Pallardy M and Biola-Vidamment A (2016) Glucocorticoid-induced leucine zipper is expressed in human neutrophils and promotes apoptosis through Mcl-1 down-regulation. $J$ Innate Immun 8:81-96.

Fan H and Morand EF (2012) Targeting the side effects of steroid therapy in autoimmune diseases: the role of GILZ. Discov Med 13:123-133.

Fry AC and Farrington K (2006) Management of acute renal failure. Postgrad Med $J$ 82:106-116.

Gu R, Tang W, Lei B, Ding X, Jiang C, and Xu G (2017) Glucocorticoid-induced leucine zipper protects the retina from light-induced retinal degeneration by inducing Bcl-xL in rats. Invest Ophthalmol Vis Sci 58:3656-3668.

Guo L, Lee HH, Noriega ML, Paust HJ, Zahner G, and Thaiss F (2016) Lymphocytespecific deletion of IKK2 or NEMO mediates an increase in intrarenal Th17 cells and accelerates renal damage in an ischemia-reperfusion injury mouse model. $\mathrm{Am}$ $J$ Physiol Renal Physiol 311:F1005-F1014.

Hueper K, Gutberlet M, Bräsen JH, Jang MS, Thorenz A, Chen R, Hertel B, Barrmeyer A, Schmidbauer M, Meier M, et al. (2016) Multiparametric functional MRI non-invasive imaging of inflammation and edema formation after kidney transplantation in mice. PLoS One 11:e0162705.

Inoue T and Okusa MD (2015) Neuroimmune control of acute kidney injury and inflammation. Nephron 131:97-101.
Iwashima M and Love R (2013) Potential of targeting TGF- $\beta$ for organ transplant patients. Future Med Chem 5:281-289.

Jang HR and Rabb H (2009) The innate immune response in ischemic acute kidney injury. Clin Immunol 130:41-50.

Jang HR and Rabb H (2015) Immune cells in experimental acute kidney injury. Nat Rev Nephrol 11:88-101.

Jones SA, Perera DN, Fan H, Russ BE, Harris J, and Morand EF (2015) GILZ regulates Th17 responses and restrains IL-17-mediated skin inflammation. $J$ Autoimmun 61:73-80.

Kalyan S and Kabelitz D (2014) When neutrophils meet T cells: beginnings of a tumultuous relationship with underappreciated potential. Eur J Immunol 44: $627-633$.

Kinsey GR, Sharma R, Huang L, Li L, Vergis AL, Ye H, Ju ST, and Okusa MD (2009) Regulatory T cells suppress innate immunity in kidney ischemia-reperfusion injury. J Am Soc Nephrol 20:1744-1753.

Kinsey GR, Sharma R, and Okusa MD (2013) Regulatory T cells in AKI. J Am Soc Nephrol 24:1720-1726.

Kluger MA, Melderis S, Nosko A, Goerke B, Luig M, Meyer MC, Turner JE, MeyerSchwesinger C, Wegscheid C, Tiegs G, et al. (2016) Treg17 cells are programmed by Stat3 to suppress Th17 responses in systemic lupus. Kidney Int 89:158-166.

Ko GJ, Zakaria A, Womer KL, and Rabb H (2010) Immunologic research in kidney ischemia/reperfusion injury at Johns Hopkins University. Immunol Res 47:78-85.

Kourtzelis I, Mitroulis I, von Renesse J, Hajishengallis G, and Chavakis T (2017) From leukocyte recruitment to resolution of inflammation: the cardinal role of integrins. J Leukoc Biol 102:677-683.

Lauriat S and Linas SL (1998) The role of neutrophils in acute renal failure. Semin Nephrol 18:498-504.

Li L and Okusa MD (2010) Macrophages, dendritic cells, and kidney ischemiareperfusion injury. Semin Nephrol 30:268-277.

Ma Y, Yabluchanskiy A, Iyer RP, Cannon PL, Flynn ER, Jung M, Henry J, Cates CA Deleon-Pennell KY, and Lindsey ML (2016) Temporal neutrophil polarization following myocardial infarction. Cardiovasc Res 110:51-61.

Makris K and Spanou L (2016) Acute kidney injury: definition, pathophysiology and clinical phenotypes. Clin Biochem Rev 37:85-98.

Maletto BA, Ropolo AS, Alignani DO, Liscovsky MV, Ranocchia RP, Moron VG, and Pistoresi-Palencia MC (2006) Presence of neutrophil-bearing antigen in lymphoid organs of immune mice. Blood 108:3094-3102.

Mamat U, Wilke K, Bramhill D, Schromm AB, Lindner B, Kohl TA, Corchero JL Villaverde A, Schaffer L, Head SR, et al. (2015) Detoxifying Escherichia coli for endotoxin-free production of recombinant proteins [published correction appears in Psychol Med (2015) 14:81]. Microb Cell Fact 14:57.

Melnikov VY, Faubel S, Siegmund B, Lucia MS, Ljubanovic D, and Edelstein CL (2002) Neutrophil-independent mechanisms of caspase-1- and IL-18-mediated ischemic acute tubular necrosis in mice. J Clin Invest 110:1083-1091.

Menke J, Sollinger D, Schamberger B, Heemann U, and Lutz J (2014) The effect of ischemia/reperfusion on the kidney graft. Curr Opin Organ Transplant 19: 395-400.

Mozaffari MS, Abdelsayed R, Patel C, Wimborne H, Liu JY, and Schaffer SW (2010) Differential effects of taurine treatment and taurine deficiency on the outcome of renal ischemia reperfusion injury. J Biomed Sci 17 (Suppl 1):S32.

Neugarten J, Golestaneh L, and Kolhe NV (2018) Sex differences in acute kidney injury requiring dialysis. BMC Nephrol 19:131.

O'Neal JB, Shaw AD, and Billings FT IV (2016) Acute kidney injury following cardiac surgery: current understanding and future directions. Crit Care 20:187.

Rabb H, Daniels F, O’Donnell M, Haq M, Saba SR, Keane W, and Tang WW (2000) Pathophysiological role of $\mathrm{T}$ lymphocytes in renal ischemia-reperfusion injury in mice. Am J Physiol Renal Physiol 279:F525-F531.

Ratman D, Vanden Berghe W, Dejager L, Libert C, Tavernier J, Beck IM, and De Bosscher K (2013) How glucocorticoid receptors modulate the activity of other transcription factors: a scope beyond tethering. Mol Cell Endocrinol 380: 41-54

Riccardi C, Cifone MG, and Migliorati G (1999) Glucocorticoid hormone-induced modulation of gene expression and regulation of T-cell death: role of GITR and GILZ, two dexamethasone-induced genes. Cell Death Differ 6:1182-1189.

Ricci E, Ronchetti S, Pericolini E, Gabrielli E, Cari L, Gentili M, Roselletti E, Migliorati G, Vecchiarelli A, and Riccardi C (2017) Role of the glucocorticoidinduced leucine zipper gene in dexamethasone-induced inhibition of mouse neutrophil migration via control of annexin A1 expression. FASEB J 31:3054-3065.

Ronchetti S, Migliorati G, and Riccardi C (2015) GILZ as a mediator of the antiinflammatory effects of glucocorticoids. Front Endocrinol (Lausanne) 6:170.

Schneider CA, Rasband WS, and Eliceiri KW (2012) NIH Image to ImageJ: 25 years of image analysis. Nat Methods 9:671-675.

Schröppel B and Legendre C (2014) Delayed kidney graft function: from mechanism to translation. Kidney Int 86:251-258.

Spurgeon-Pechman KR, Donohoe DL, Mattson DL, Lund H, James L, and Basile DP (2007) Recovery from acute renal failure predisposes hypertension and secondary renal disease in response to elevated sodium. Am J Physiol Renal Physiol 293: F269-F278.

Srinivasan M and Lahiri DK (2017) Glucocorticoid-induced leucine zipper in central nervous system health and disease. Mol Neurobiol 54:8063-8070.

Thornton MA, Winn R, Alpers CE, and Zager RA (1989) An evaluation of the neutrophil as a mediator of in vivo renal ischemic-reperfusion injury. Am J Pathol 135: 509-515.

Torras J, Herrero-Fresneda I, Lloberas N, Riera M, Ma Cruzado J, and Ma Grinyó J (2002) Promising effects of ischemic preconditioning in renal transplantation. Kidney Int 61:2218-2227.

Vago JP, Tavares LP, Garcia CC, Lima KM, Perucci LO, Vieira ÉL, Nogueira CR Soriani FM, Martins JO, Silva PM, et al. (2015) The role and effects of glucocorticoid-induced leucine zipper in the context of inflammation resolution. J Immunol 194:4940-4950. 
Velic A, Gabriëls G, Hirsch JR, Schröter R, Edemir B, Paasche S, and Schlatter E (2005) Acute rejection after rat renal transplantation leads to downregulation of $\mathrm{NA}+$ and water channels in the collecting duct. Am J Transplant 5:1276-1285.

Wang S, Diao H, Guan Q, Cruikshank WW, Delovitch TL, Jevnikar AM, and Du C (2008) Decreased renal ischemia-reperfusion injury by IL-16 inactivation. Kidney Int 73:318-326.

Yang CW and Unanue ER (2013) Neutrophils control the magnitude and spread of the immune response in a thromboxane A2-mediated process. J Exp Med 210: $375-387$.
Yang N, Baban B, Isales CM, and Shi XM (2017) Role of glucocorticoid-induced leucine zipper (GILZ) in inflammatory bone loss. PLoS One 12:e181133.

Zuk A and Bonventre JV (2016) Acute kidney injury. Annu Rev Med 67:293-307.

Address correspondence to: Dr. Mahmood S. Mozaffari, Department of Oral Biology and Diagnostic Sciences; CL-2134, Dental College of Georgia, Augusta University, Augusta, GA 30912-1128. E-mail: mmozaffa@augusta.edu 